\title{
Between Hipparchian Cynicism and Priscillian Montanism: Some Notes on Tatian, or. 3.6
}

\author{
Josef Lössl \\ Cardiff University, School of History, Archaeology and Religion \\ LosslJ@cardiff.ac.uk
}

\begin{abstract}
Tatian's Oration to the Greeks (or.) contains a list of twelve ancient Greek philosophers whom Tatian berates for their arrogant stupidity (or. 2.1-3.7). In this list can be found a brief note (or. 3.6) in which Tatian singles out the Cynic Crates of Thebes (ca. 368/5-ca. 288/5 BC) and asks who would want to be a witness at his "dog-marriage"

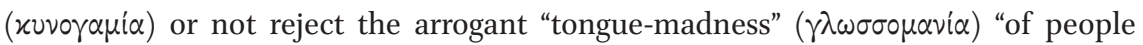
like him" rather than "seeking that which is truly worth pursuing." This paper aims at contributing to an improved understanding of this sentence and in particular of the

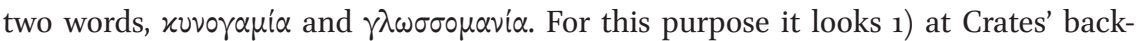
ground, in particular his marriage with Hipparchia of Maroneia, and 2) at the wider context in which Tatian is writing, in particular the phenomenon of early Christian ecstatic prophecy personified by the leading Montanist women prophets Priscilla and Maximilla.
\end{abstract}

\section{Keywords}

Tatian - Crates of Thebes - Hipparchia of Maroneia - Montanus - Priscilla Maximilla - Cynicism - Montanism - Encratism - ancient marriage - prophecy

\section{Introduction}

Tatian's Oratio ad Graecos (or.), completed in Antioch between 172 and $180 \mathrm{AD},{ }^{1}$ is famous, some might say notorious, for its detraction of everything Greek.

1 For the likely date and location see J. Lössl, "Date and Location of Tatian's Ad Graecos: Some Old and New Thoughts," StPatr 74 (2016) 43-55. It was probably completed towards the end of 
However, a closer look reveals that it contains not only negative polemics but also a lot of rare (in some cases unique) information that is interesting in terms of cultural and intellectual history, in particular the history of Christian intellectual culture in the second century.

For the sake of simplification one could distinguish between two fundamental types of passages in or., those in which Classical Greek culture is attacked and vilified ${ }^{2}$ and those in which the superior achievements of barbarian culture and the teachings of the barbarian philosophy are praised and positively set out and developed. ${ }^{3}$ Interesting and useful information of the kind mentioned above is contained in passages of both types and sometimes even very short passages, sentences, clauses, phrases, or single words, can yield such information and help towards a better understanding of the text and the thought world in which it originated.

In implementing this principle this article will focus on just one sentence, or. 3.6, a dismissive remark about the Cynic philosopher Crates of Thebes (ca. 368/5-288/5 BC), pupil of the more well-known Diogenes of Sinope (ca. 405-320 BC), who is mentioned in or. 2.1. The intention of the article is to explore this brief remark with a view towards its author's attitude to and knowledge of certain types of Greek philosophy and its main protagonists. Beyond that it will also ask whether Tatian's handling of his material may perhaps reveal something about his self-positioning as a Christian teacher, for example with regard to marriage and to women as teachers and religious leaders.

that period, i.e. closer to 180 than to 172. For the text, modern translation and guiding notes of or. we will hereinafter rely mainly on H.-G. Nesselrath, Gegen falsche Götter und falsche Bildung. Tatian, Rede an die Griechen (Tübingen, 2016).

2 Including or. 1-3, 8-11, 16-19, 21-28. To be precise, or. 1 begins with a list of cultural inventions achieved by ancient barbarians from different cultures, but the purpose of that list is not to glorify these barbarian cultures but to put down the Greeks who could not claim those achievements for themselves.

3 Including or. 4-7, 12-15, 20, 29-30, 36-41. By "barbarian philosophy” Tatian invariably refers to what could be commonly understood as "Christianity," a word he never uses; for his use of "barbarism" see now S. E. Antonova, Barbarian or Greek? The Charge of Barbarism and Early Christian Apologetics (Leiden, 2019), especially 129-211; but continue to see P. Gemeinhardt, "Tatian und die antike Paideia. Ein Wanderer zwischen zwei (Bildungs-)Welten," in Nesselrath, Gegen falsche Götter (n. 1), 247-266 and J. Lössl, "Bildung? Welche Bildung' Zur Bedeutung der Ausdrücke 'Griechen' und 'Barbaren' in Tatians Rede an die Griechen,” in F. R. Prostmeier (ed.), Frühchristentum und Kultur (Freiburg i. Br., 2007), 127-154 on the link between Tatian's notion of 'the barbarian' and his understanding of Greek education (Paideia). 
Greek philosophy is one of the areas of Greek culture which Tatian detracts in or. As early as or. 2-3 he lists at least eleven ${ }^{4}$ of the most eminent ${ }^{5}$ ancient Greek philosophers and mocks them for various foibles that make them ridiculous in his eyes. ${ }^{6}$ The central (common) flaw of their personalities and their teachings, in his view, is their arrogance. ${ }^{7}$ This is linked to the high opinion each of them has of his particular teaching, which he considers his very own intellectual achievement. Each of them, according to Tatian, is therefore quite consistent in appearing stupidly arrogant while claiming to practise his teaching. The personal arrogance and stupidity of each of them is intrinsically linked to and therefore consistent with that teaching. Diogenes the Cynic, for example, who was so proud of the wooden barrel that was his home, because it symbolised his $\alpha \dot{v} \tau \dot{\alpha} p x \varepsilon i \alpha$, was entirely consistent when, in his lack of self-restraint ( $\left.\alpha x p \alpha \sigma^{\prime} \alpha\right)$, defying ordinary conventions, he ate raw Octopus, contracted food poisoning and died a horrible death, ripped apart internally by violent cramps. ${ }^{8}$ Aristippus, too, was consistent. "Parading in

4 They include, in this order, Diogenes, Aristippus and Plato (2.1), Aristotle and his pupil Alexander the Great (2.2), the Aristotelians of Tatian's time (2.3), Heraclitus (3.1-2), Zeno (3.3), Empedocles (3.4), Pythagoras, Pherecydes and, once more, Plato (3.5), and Crates (3.6). Although only eleven individuals are included here, twelve names are listed, as Plato is mentioned twice, first in connection with his stay, together with the Hedonist Aristippus, at Dionysius' court in Syracuse, and the second time because of his subscription to Pythagoras's teaching of the migration of souls. Moreover, Aristotelians of Tatian's time (i.e. "people who

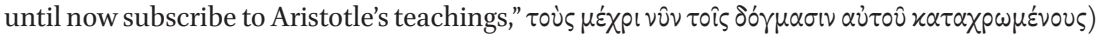
are mentioned in 2.3. Finally, as will be discussed in this article, the reference to Crates in 3.6 could include more than one hidden reference to Crates's wife Hipparchia.-There is another list of Greek philosophers and their foibles in or. 25.1-4, and in 19.2 Tatian mentions the philosopher Crescens, an opponent of his teacher Justin (cf. 2 apol. 3.1-2, 11.2). I will discuss these passages elsewhere.

5 "O so serious," $\pi \alpha \dot{v} v \sigma \pi 0 v \delta \alpha i o l$, is how he refers to them in his initial address, or. 2.1.

6 He makes his disparagement clear from the outset: "What great and eminent achievement ( $\left.\sigma \varepsilon \mu \nu v^{\prime}\right)$ is it that you can claim?" He asks, rhetorically. "None," is the reply he would expect. In his view, they all fell for the vice of boastfulness, $\dot{\alpha} \lambda \alpha \zeta o v \varepsilon i \alpha$. What this word entails is illustrated in 3.4, where Empedocles is specifically ridiculed for his mad scheme to jump into the crater of Mount Etna to prove his divinity. Tatian refers to this act as a vehicle or device of

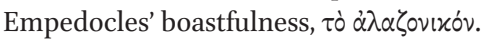

7 See above n. 6 on or. 2.1 and 3.4 ( $\alpha \lambda \alpha \zeta o v \varepsilon i \alpha, \dot{\alpha} \lambda \alpha \zeta$ ovixóv), but also (e.g.) $\alpha \alpha \dot{x} \chi \eta \mu \alpha$ in the case

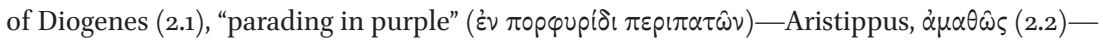

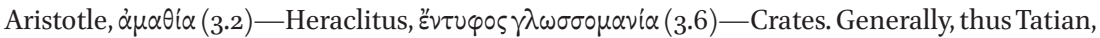

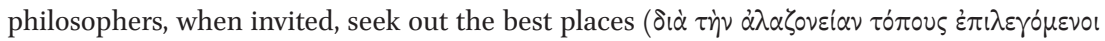

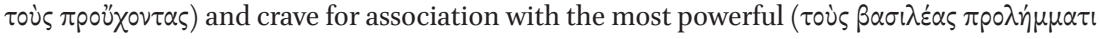

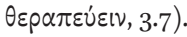

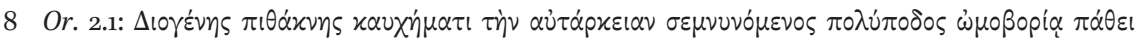
$\sigma \nu \sigma \chi \varepsilon \theta \varepsilon i \zeta \varepsilon i \lambda \varepsilon \hat{\omega} \delta \dot{\alpha} \alpha \dot{\eta} \nu \dot{\alpha} x p \alpha \sigma i \alpha \nu \dot{\alpha} \pi 0 \tau \dot{\varepsilon} \theta \nu \eta x \varepsilon v$. 
purple" and encouraging the luxurious life at Dionysius' court was entirely in tune with his hedonistic teachings. ${ }^{9}$ Plato in contrast was a failure-as far as Tatian is concerned-both as a person and a philosopher. Not only did he prove to be a hypocrite by his own high standards, trying to endear himself to Dionysius, a vainglorious tyrant, but with his philosophizing he was also nothing but a useless eater to Dionysius. Aristippus could at least teach Dionysius' cooks some sophisticated new recipes and entertain the tyrant at his drinking parties (by dancing and making witty remarks). Useless Plato, in contrast, was sold into slavery, to make up for the expenses he had run up at Dionysius' court. ${ }^{10}$

And so it continues: Alexander the Great was a pupil of Aristotle. He learnt from his master to hold lavish banquets and to kill his friends when they began

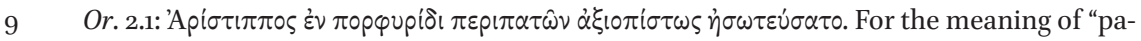

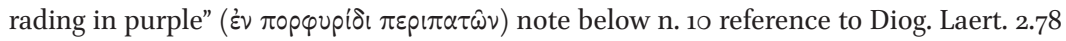
( $\dot{\varepsilon} \nu \pi \circ \rho \varphi \cup \rho \hat{\imath} \dot{\varepsilon} \sigma \theta \hat{\eta} \tau \iota ~ \partial ่ \rho X \dot{\eta} \sigma \alpha \sigma \theta \alpha \mathrm{l})$. Some modern translators seem to have misunderstood $\dot{\alpha} \xi ı \pi i \sigma \tau \omega \varsigma$ ("credibly"), which is used here without irony. In Tatian's opinion Aristippus behaves in this outrageous manner without any pretence or hypocrisy but consistent with his philosophy. This is acknowledged by Nesselrath, Gegen falsche Götter (n. 1), 41, who translates "auf glaubwürdige Weise," but not by J. Trelenberg, Tatianos. Oratio ad Graecos / Rede an die Griechen (Tübingen, 2012), 89: "Wie glaubwürdig!," S. Di Cristina, Taziano il Siro. Discorso ai Greci (Rome, 1991), 54: "sotto le apparenze," M. Whittaker, Tatian. Oratio ad Graecos and Fragments (Oxford, 1982), 5: "under a cloak of respectability," R. Kukula, Tatians Rede an die Bekenner des Christentums (Kempten, 1913), 197 [23]: "scheinheiliger Lüstling," and A. Puech, Recherches sur le Discours aux Grecs de Tatien (Paris, 1903), 109: "sous un masque de gravité."

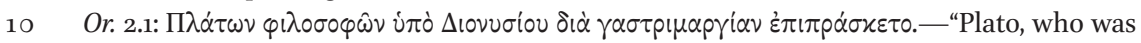
philosophizing, was sold as a slave by Dionysius because of his gluttony." Quite clearly, $\varphi(\lambda \circ \sigma \circ \varphi \hat{\omega} v$ is here said of Plato in contrast to Aristippus' activities at Dionysius' court. The charge of $\gamma \alpha \sigma \tau p \mu \alpha \rho \gamma i \alpha$, "gluttony," is credible because, obviously, Plato would have participated in the lavish banquets held at court. But unlike Aristippus he would—with his philosophizing - have turned out to be of little use to Dionysius. Therefore, his being sold off as a slave in the manner in which prisoners of war are sold into slavery (= $\dot{\pi} 1 \pi \rho \alpha \dot{\sigma} \sigma \varepsilon \tau 0)$. Tatian's linking of Plato and Aristippus and placing them at Dionysius' court could be influenced by Diog. Laert. 2.78, who reports that once, at a drinking party, Dionysius ordered both philosophers to put on purple dresses and dance. While Aristippus complied, Plato declined. Lucian, parasit. 33-34, too, reports that Plato was banned from Dionysius' court because of uselessness $\left(\dot{\alpha} \varphi v^{i} \alpha\right)$ and stupidity $\left(\dot{\alpha} \mu \alpha \theta_{i} \alpha\right)$, while Aristippus was ordered by Dionysius to teach his cooks some new recipes. But Lucian does not go as far as to suggest that Plato was subsequently sold into slavery. Later sources who report Plato being sold into slavery because of his gluttony may depend on Tatian, e.g. Tert. apol. 46.15:

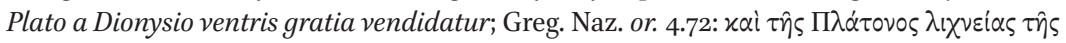

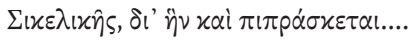




\section{to dare criticise him. ${ }^{11}$ Plato mimicked Pythagoras, though some of his follow- ers would not have this. ${ }^{12}$}

Or. 2.2. Here Tatian also criticizes Aristotle's teachings that there is no providence ( $\pi$ póvol $\alpha$ ) in the sublunar world and that the essence of happiness ( $\left.\varepsilon \dot{v} \delta \alpha \mu{ }^{\prime} v^{\prime} \alpha\right)$ can be deduced from everyday pleasures (alluding to the eudaemonic principle of his ethics). But his most vociferous polemic is against Aristotle's flattering ( $\dot{\varepsilon} x \circ \lambda \dot{\alpha} \kappa \varepsilon v \varepsilon v)$ behaviour towards the "crazy

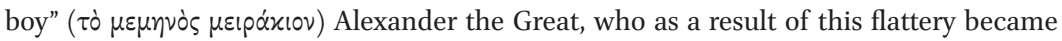
unable to accept any criticism from anyone. He later locked up an adviser (Aristotle's grand-nephew Kallisthenes) in a cage and killed his best friend (Kleitos) in a drunken

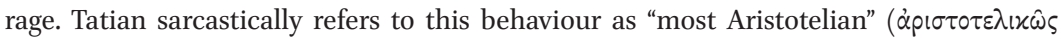
$\pi \alpha \dot{v v)}$ because he sees it as the result of Aristotle's flattery. According to Lucian, dial. mort. 13.5, too, flattery is the single most reprehensible trait of Aristotle's attitude towards Alexander the Great, in fact so much so that even Alexander himself is disgusted by it:

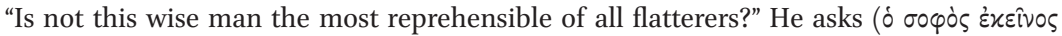

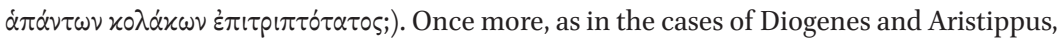
Tatian sees no inconsistency between Aristotle's teachings and Alexander's behaviour.

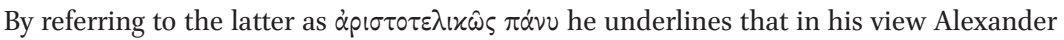
was not a bad but a rather "good" student of Aristotle and his rotten philosophy (i.e. his "eudaemonism").

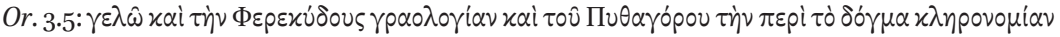

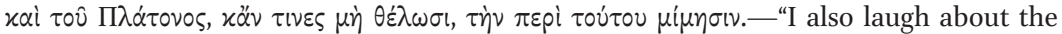
fairy tales of Pherecydes, the teaching of Pythagoras, [i.e.] his [scil. Pherecydes'] legacy, and Plato's imitation of the latter, although some deny this." The opening "I also laugh" ( $\gamma \varepsilon \lambda \hat{\omega} x \alpha i)$ alludes back to the opening of or. 2.3, Tatian's report on the Aristotelians of his own time, who "to the present day" ( $\mu \dot{\varepsilon} \chi \rho \mathrm{\rho} \iota$ vô) held that providence did not extend to the sublunar world and that people who lacked beauty, wealth and a healthy body could not possibly be happy. There, Tatian had used the optative Aorist $\gamma \varepsilon \lambda \dot{\alpha} \sigma \alpha u \mu$, "let me laugh ..." He had also closed the passage with an optative: "And such people want to be philosophers?" After that he had continued with accounts on Heraclitus (2.3-3.1), Zeno (3.2) and Empedocles (3.3) condemning the arrogance of each of these in turn: Heraclitus' autodidacticism, a folly ( $\left.\alpha \mu \alpha \theta^{\prime} \alpha\right)$ that eventually led to his gruesome demise, Zeno's doctrines of Ekpyrosis and the presence of God even in the lowest forms of life such as worms and evildoers, and Empedocles' spurious claim to divinity. The link between Pherecydes, Pythagoras and Plato in or. 3.5 refers to a report the earliest extant witness of which is Cic. Tusc. 1.38-39, where Pherecydes is first said to have claimed that the human souls are "everlasting" (Pherecydes Syrius primus dixit animos esse hominum sempiternos). Pythagoras, Cicero continues, had confirmed this and Plato had underpinned it with arguments. Tatian, who reiterates or. 25.3 that Pythagoras was Pherecydes' heir ( $\tau 0 \hat{v}$

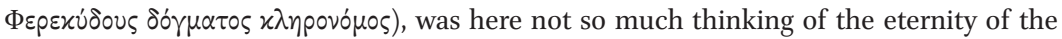
soul in the sense of its immortality (in which he did not believe in an unqualified manner;

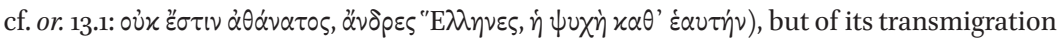
(metempsychosis). According to Clem. Alex. strom. 6.27.2 the teaching of the soul's immortality originated in Egypt, where Pythagoras learnt it, later to pass it on to Plato (i.e. it did not originate from Pherecydes' teaching). Cicero's passage also suggests that Plato was widely seen as having developed Pythagoras' teaching and not just as having mimicked it (cf. also Diog. Laert. 3.9 on Plato buying Philolaos' writings on Pythagoras' teachings, thus making them accessible to the world; ibid. 8.15, 84). It is against this (widespread) 
Thus, finally, Tatian comes to Crates..$^{13}$ A Cynic like Diogenes, with whom Tatian's list of philosophers had opened in or. 2.1, and in fact a pupil of Diogenes, ${ }^{14}$ Crates was different from Diogenes, not harsh (a trait that contributed to the latter's bizarre demise) but charming and popular with people, who were happy to receive his advice, which he was only too happy to give. ${ }^{15}$ With regard to him, Tatian makes the following point:

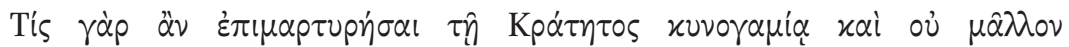

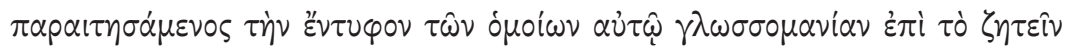

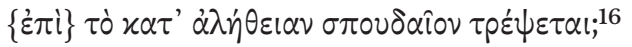

For who would have witnessed Crates' 'dog-marriage' and not rejected the arrogant 'tongue madness' of people like him, turning instead to what is truly serious?

At a first (superficial) glance it might seem that Tatian is here only making one point: Crates is to be avoided on account of his reprehensible personal behaviour (symbolised by his dog-marriage) and his mad teachings ( $\left.\gamma \lambda \omega \sigma \sigma o \mu \alpha v^{\prime} \alpha\right)$. Instead the true philosophy (i.e. a Platonism-inspired Christian philosophy)

view that Tatian holds that "some would not have it" ( $\tau$ mimicked Pythagoras.

13 Or. 3.6; Crates of Thebes, ca. 368/5-288/5 BC; for a survey of his background, life and thought see A. A. Long, "The Socratic Tradition: Diogenes, Crates and Hellenistic Ethics," in R. Bracht Branham and M.-O. Goulet-Cazé (eds.), The Cynics: The Cynic Movement in Antiquity and Its Legacy (Berkeley, CA, 1996), 28-46; M.-O. Goulet-Cazé, "Cratès de Thèbes," Dictionnaire des Philosophes Antiques 2 (1994) 496-5oo; more recently also id., "Kynismus," RAC 22 (2008) 631-87 at 632-36; for the sources see also G. Giannantoni (ed.), Socraticorum Reliquiae 1.4 (Naples, ${ }^{2} 1990$ ), commentary in vol. 4, 561-66.

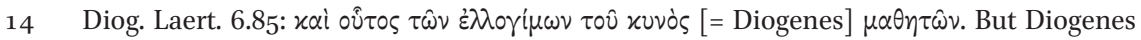
also knows of an alternative tradition, according to which Bryson the Achaean was Crates' teacher.

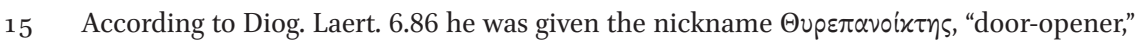
because of his habit of entering houses and "admonishing" ( or. 6. 201 B relates that unlike Diogenes he did so "not harshly, but charmingly," ह่ $\pi \varepsilon \tau i \mu \alpha$ o $\mu \varepsilon \tau \dot{\alpha} \pi i x p \dot{i} \alpha \varsigma, \dot{\alpha} \lambda \lambda \dot{\alpha} \mu \varepsilon \tau \dot{\alpha} \chi \dot{\alpha} \operatorname{pi\tau o\varsigma .~}$

16 Or. 3.6 (following the text of Nesselrath, Gegen falsche Götter [n. 1], 42). The second ż $\pi \grave{\imath}$ (between brackets) is a reading contained in all medieval manuscripts which was deleted by the first modern editor (Conrad Gesner), who was followed by Otto, Schwartz, Goodspeed and Whittaker. It has been reinstated (between brackets) by Trelenberg,

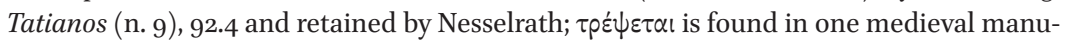
script and followed by Otto, Schwartz, Goodspeed, Whittaker and Nesselrath. Some other

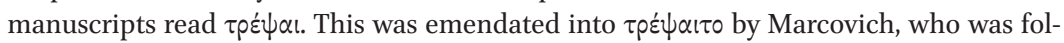
lowed by Trelenberg. 
ought to be pursued. ${ }^{17}$ Such a reading is of course correct considering that $o r$. is essentially a philosophical protreptic. ${ }^{18}$ But, as will be argued in this article, Tatian's frequent use of idiosyncratic and rare (and in the case of $\gamma \lambda \omega \sigma \sigma o \mu \alpha v^{\prime} \alpha$ even unique) vocabulary may warrant further exploration of possible deeper implications of the use of these expressions. Their use could be linked to Hipparchia, who is not mentioned by name, and to Tatian's stance vis à vis women philosophers and indeed vis à vis Christian women teachers and spiritual leaders more widely. In the following sections therefore both expressions in question, $x v v 0 \gamma \alpha \mu i \alpha$ and $\gamma \lambda \omega \sigma \sigma o \mu \alpha v^{\prime} \alpha$, will be discussed in turn before the article will draw to a close with some tentative conclusions.

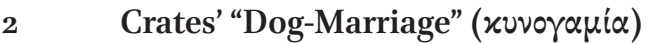

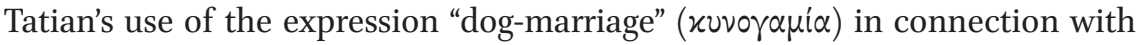
Crates is strongly allusive. The reference could not be understood without at least some degree of knowledge of Crates' biography among the intended audience, ${ }^{19}$ knowledge of a kind that seems not to have been shared any more by the Byzantine scribes who transmitted the manuscript readings xoivorauia and xolvorapia.. ${ }^{20}$ This is not totally insignificant. The manuscript readings

17 Note with regard to the latter point that in or. 29.2 Tatian writes that as he was seeking for himself that which ought to be pursued in philosophy ( $\tau \dot{\alpha} \sigma \pi \circ v \delta \alpha i \alpha)$ he came across the "barbarian writings," i.e. Scripture. This is how Tatian describes his conversion. Therefore his use here in 3.6 of the verb $\tau p \varepsilon \dot{\psi} \varepsilon \varepsilon \tau \alpha$ l is also significant. For the significance of the concept of $\tau \dot{0} \sigma \pi \circ v \delta \alpha \hat{o} v$ for Tatian's Platonist inclinations see M. Elze, Tatian und seine Theologie (Göttingen, 1960), 29-32. See also or. 2.1 his sarcasm about the "oh so serious" ( $\pi \dot{\alpha} v v \sigma \pi \circ v \delta \alpha i ̂ \iota)$ ancient philosophers.

18 For reading or. as a protreptic see M. McGehee, "Why Tatian Never 'Apologized' to the Greeks," JECS 1 (1993) 143-158.

19 Note here that the audience that is expressly mentioned in or. $(1.1 ; 4.1 ; 12.6 ; 13.1 ; 21.1,5 ; 25.5$

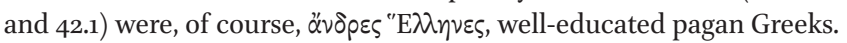

20 Paris, BnF, ms. gr. 174 (12th c.) and Venice, BnM, cod. gr. z. 343 (= 309) (11th c.) have

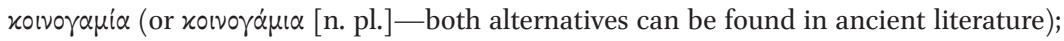
Modena, Biblioteca Estense, alfa.s.5.9 = gre. 126 (11th c.) has xorvorapiat. LSJ translates the word as "promiscuous concubinage," the only classical reference being Clearch. frg. 73 apud Athen. deipn. 13.555c, who reports that Kekrops first introduced monogamy

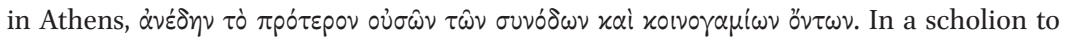

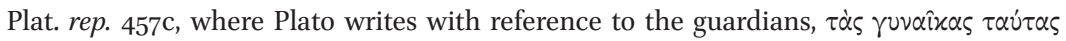

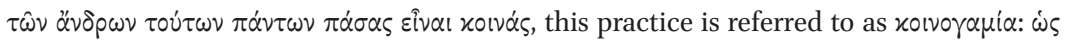

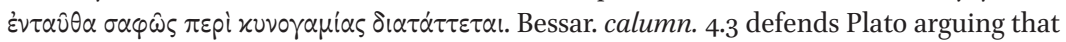
surely Plato would not have intended to advocate a licentious lifestyle but a rational practice; he therefore had to be understood from the context of his time. Perhaps it was in

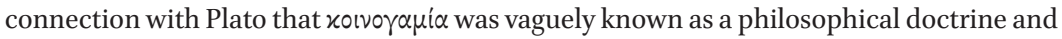


were retained even in the early modern editions until in 1700 William Worth cautiously suggested with reference to the doxographical accounts that, prob-

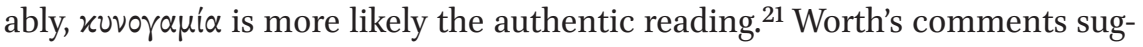
gest that it may have been precisely Tatian's omission of Hipparchia's name that contributed to the misreading; for whatever Tatian says of Crates, it seems

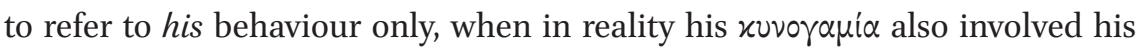
wife Hipparchia, a powerful and renowned Cynic philosopher in her own right. $^{22}$ This was widely known and generally acknowledged in Antiquity, as Worth points out. ${ }^{23}$

later also associated with Crates; see e.g. Greg. Naz. or. 25.20 (although this passage could have similar text-critical issues as Tat. or. 3.6).

21 W. Worth, Tatiani Oratio ad Graecos ... (Oxford, 170o), 15 n. 2. Worth's intervention is not just of text-critical significance. It reckons at least with the possibility that Tatian and his intended audience may still have had a relatively nuanced and informed understanding of the word $x v v 0 \gamma \alpha \mu i \alpha$ in connection with Crates and Hipparchia. Otherwise (see for this

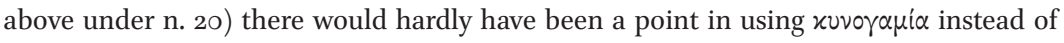
xovvorapia. If the purpose of or. 3.6 was to denigrate Crates with some cheap sexual slander (rather than to provide also a piece of sophisticated and correct information on him), either word would have done. The possibility that Tatian really did use $x v v o \gamma \alpha \mu i \alpha$ raises the stakes regarding his rhetoric in the way suggested in this article.

22 For a relatively recent study introducing to the sources related to Hipparchia and her teaching see L. Grams, "Hipparchia of Maroneia, Cynic Cynosure," Ancient Philosophy 27 (2007) 335-350; though K. Kennedy, "Hipparchia the Cynic: Feminist Rhetoric and the Ethics of Embodiment," Hypatia 14 (1999) 48-71, is also still worth consulting; the main information is gathered in J. M. García Gonzáles and P. P. Fuentes Gonzáles, "Hiparchia de Maronée," Dictionnaire des Philosophes Antiques 3 (2000) 742-50.

23 Cf. ibid.: xolvorapia] De mendo mihi suspecta est vox ista ... Certe nusquam legimus communes nuptias à Cratete approbatas; quin et meretrices convitiis insectari, ex industria, solitum esse testatur Laertius in vita eius. Unam autem uxorem Crateti nupsisse, Hipparchiam Maronitim, praeter Laertium testatur Clemens [= strom. 4.19.121.6; see below]. Worth here takes up an ancient debate in which one side tried to equate Crates' and Hipparchia's marriage behaviour such as men consorting with prostitutes ( $\pi$ opvei $\alpha$ ), while the other side insisted that there was a fundamental difference; for numerous references see K. Döring, "Sokrates, die Sokratiker und die von ihnen begründeten Traditionen," in: H. Flashar (ed.), Die Philosophie der Antike, Grundriss Antike 2/r: Sophistik. Sokrates. Sokratik. Mathematik. Medizin (= Überweg Grundriss der Geschichte der Philosophie; Basel, 1998), 297-300 at 299-300. The debate seems to have been about nuances between decent and moral. Was it the public nature of a sexual act that made it immoral, and what exactly constituted the public nature of a sexual act? According to some the practice of visiting prostitutes constituted an indecent and immoral public sexual act, although the sexual activity itself may have taken place behind closed doors, while Crates and Hipparchia were understood by many as having performed a legitimate marital act, although the fact that they did so in full view of the public was widely perceived as a violation of public decency (though not necessarily immoral). This nuance is particularly obvious in Apul. flor. 14.1-5, where Crates and Hipparchia are depicted as performing their act in full public view, while Crates' 
The word xoเvo $\alpha \mu i \alpha$ also reminds of the practice of early Christian heresiologists of accusing some Gnostic groups of promiscuous sexual behaviour, ${ }^{24}$ although apparently the word itself cannot be found in this context anywhere in early Christian literature. If Tatian indeed used it, it would be another one of those very rare or unique words which he occasionally used, such as $\gamma \lambda \omega \sigma \sigma o \mu \alpha v i \alpha$, which will be discussed in the next section. If it is the result of a scribal error, it could have arisen from a misunderstanding about the nature of

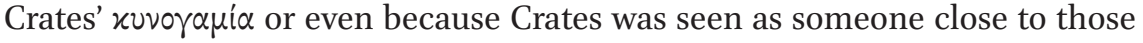
early Christians who advocated xovvoyapia. Tatian, of course, who was himself accused of advocating a deviant practice, Encratism, i.e. the rejection of any form of marriage or sexual activity of any kind, ${ }^{25}$ would have been funda-

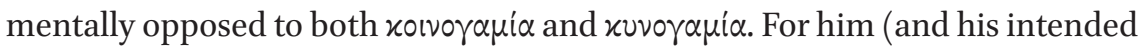
readers) either expression would have had a pejorative connotation.

One could therefore ask: Why was Tatian so elliptic and allusive in or. 3.6?

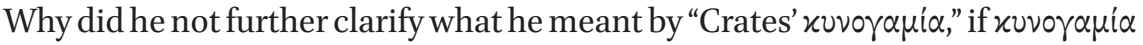
was the word he used? He could have named Hipparchia as the woman with whom Crates contracted this marriage? Did he not want to lend prominence to a married couple? Or was his first priority to suppress the memory of a

pupil Zeno desperately tries to protect the decency of the couple by holding up his cloak as a screen. There is no reason to assume, as Grams, "Hipparchia" (n. 22) 335 does, that the first detail is less of a "literary invention" than the second. Both acts-in the way in which they are depicted by Apuleius-are highly symbolic. Grams herself (ibid. n. 1) concedes as much: Apuleius' story of Crates' and Hipparchia's enthusiastic love-making in the painted

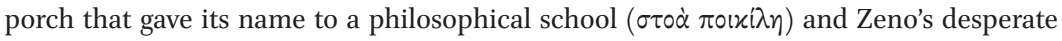
attempt to protect the couple's decency may represent a "fictional embellishment" of the bare facts related in more restrained accounts such as Sext. Emp. Pyrrh. hyp. 3.200-1; Aug. civ. 14.20 and, one may add, Diog Laert. 6.97, Sext. Emp. Pyrrh. hyp. 1.153; Clem. Alex. strom. 4.19.121.6 and Lact. div. inst. 3.15.20, as will be discussed below.

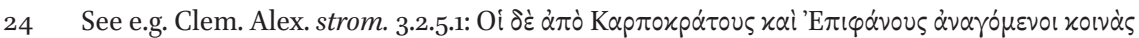

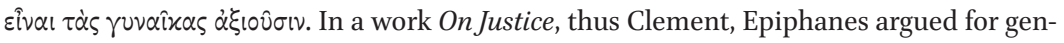
der equality (3.2.6.2 and 7.1) and for the abolition of private property including the exclu-

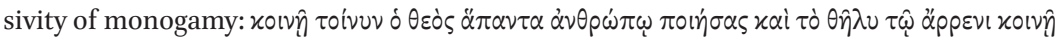

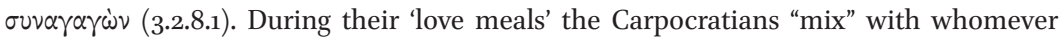
they please, although they do put out the lights to overcome their inhibitions: ... $\varphi \hat{\omega} \varsigma \tau \hat{\eta}$

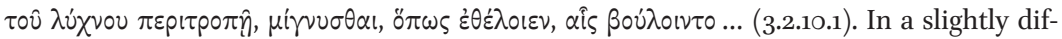
ferent way from Bessarion (see above n. 20) Clement thinks that Carpocrates misunder-

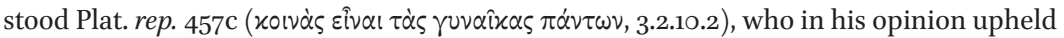
monogamy. Finally, thus Clement, Xanthos reported in his work on magic that according to the Magi women were in common, though not in secret or by force but openly and con-

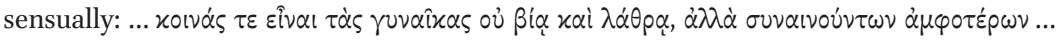
(3.2.11.1).

25 E.g. by Iren. haer. 1.28.1 apud Euseb. h. e. 4.29.2; Clem. Alex. strom. 3.12.81.1-2. Both Irenaeus and Clement advocated monogamy. 
relatively famous Greek woman philosopher? One could argue that he might not have thought Hipparchia important enough. Yet titillating stories about her marriage with Crates were still circulating in his time. Why did he not take this opportunity? Elsewhere he is wallowing in sexual innuendo denigrating Greek culture, naming lascivious goddesses, epic women characters and women on historical record, poets, actors, hetaerae, musicians, dancers. ${ }^{26}$ What prevents Tatian from adding Hipparchia to his list of notorious women, particularly in light of her being known as a Cynic philosopher of note? We shall return to this question once more towards the end of this article.

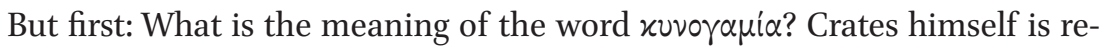
corded as referring to his marriage with Hipparchia using this word. ${ }^{27}$ If this is true, it is unlikely that the original connotation of the word was pejorative. It was not meant to refer to a marriage in which the couple might have displayed doglike behaviour or succumbed to the Cynic vice of shamelessness ( $\alpha \nu \alpha i \delta \varepsilon ı \alpha)$

26 Or. 8. Tatian names several female divinities who engage in scandalous or abhorrent behaviour, or. 10.5 he elaborates on Helen of Troy's sexual exploits, or. 33-34 he sets out a long list of women who are bad examples for the philosophizing women in his community

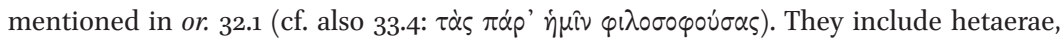
models of sculptors, poetesses and musicians such as Praxilla, Learchis, Sappho, Erinna, Myrtis, Myro, Praxagoris, Kleito, Corinna, Glaucippe, Phryne and a number of others; but (interestingly) no philosophers. Hipparchia would have been a perfect candidate.

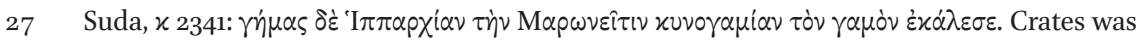
in the habit of referring to matters concerning marriage and sexual relations in a 'cynical' (i.e. unequivocal and direct) way, even if it risked causing offence. Therefore, one could get the impression that he equated marriage with prostitution $(\pi \circ p v \varepsilon i \alpha)$. But is this really the case? Diog. Laert. 6.88 reports that he once led the son whom he had with Hipparchia, Pasicles, to the 'house' (o'k $x \mu \alpha)$ of a prostitute $(\pi \alpha i \delta i \sigma \times \eta \varsigma)$ telling him that this is what he

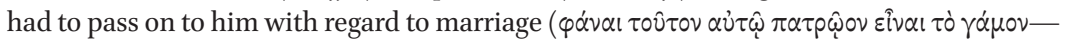
$\tau \dot{\partial}$ yá $\mu \mathrm{ov}$ here understood as an accusative of respect). It seems he understood the visit as an exercise in sex education. But the essence of what he seems to have intended to pass on to his son as an inheritance $(\pi \alpha \tau p \omega$ 个 kind of entertainment or a corrupt habit but a better understanding of potential problems attached to heterosexual relations; for significantly the passage continues with a warning that while marriage and adultery are the stuff of tragedies, prostitutes, sexual excess and drunkenness belong to comedy. It seems he warned his son of both extremes. Crates' advice offers no positive synthesis, but one may assume that Pasicles had in front of him as a model the marriage of his parents. In Diog. Laert. 6.9o we read that Crates

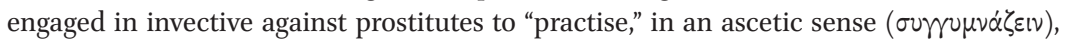

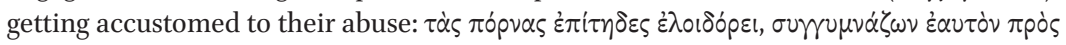
$\tau \dot{\alpha} \varsigma \beta \lambda \alpha \sigma \varphi \eta \mu i \alpha \varsigma$. At one level this has been interpreted as just one form of 'philosophical askesis' which Crates practised. Many such acts are reported of him (for a further example see below n. 41). But here it is also significant that it is prostitutes whom he attacks. The direct article in Greek ( $\tau \dot{\alpha} \varsigma)$ emphasizes that it is "their" abuse that Crates intends to practise to get used to, not any odd abuse; see for this also above n. 23 . 
but simply to a marriage between a man and a woman who both happened to be Cynic philosophers.

Of course, that too have raised questions, as 1) Cynics were not known, or supposed, to marry, and 2) a woman could not be a philosopher in her own right, let alone a Cynic. Hipparchia in contrast was a renowned Cynic philosopher. Born in Maroneia in Thrace around 350 вс her family relocated to Athens when she was a child. There, her brother Metrocles became a pupil of Crates. ${ }^{28}$ Diogenes Laertius 6.96-98 relates how she too-although still in her teens-became attached to Crates and his teachings and threatened her parents that she would kill herself if she were not allowed to marry him. Upon her parents' request Crates tried to dissuade her. When she persisted, he took off his clothes in front of her ${ }^{29}$ and, pointing out that these were all his pos-

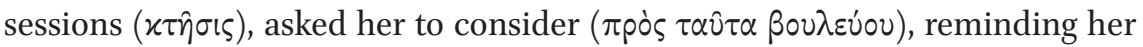
that she could only be his companion (xovvovós) if she pursued the same goals

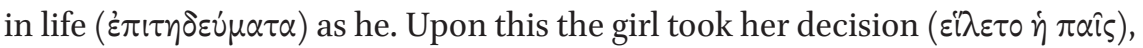
began to dress in the same outfit $(\sigma \chi \hat{\eta} \mu \alpha)$ as he and to walk about with him

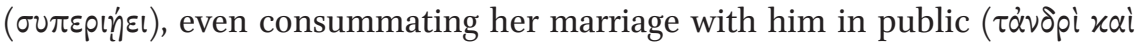

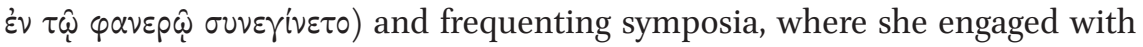
other attendants in adversarial talk. Humiliated by her prowess as a dialectician some men attacked her physically or tried to tear off her clothes. But she remained unfazed and considered it an advantage to be able to spend her life as a philosopher rather than sitting at the loom like other women. ${ }^{30}$

28 On Metrocles see Diog. Laert. 6.94; Döring, "Sokrates" (n. 23), 304-305.

29 The accounts are not entirely clear. Diog. Laert. 6.96 speaks of him taking off his clothes

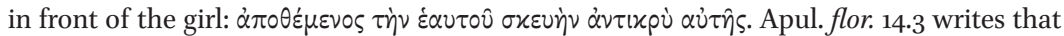
he bared his back and showed her his hunchback: ... interscapulam Crates retexisset, quod erat aucto gibbere.

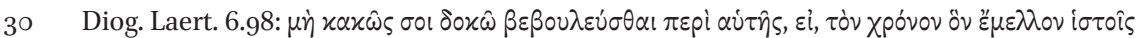

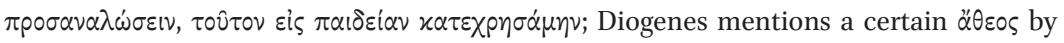
the name of Theodorus, who was defeated by Hipparchia in a dialectic contest and subsequently tried to rip off her clothes, but without success; see on him also Döring, "Sokrates" (n. 23), 261-263 (Theodoros Atheos). Suda, । 517 relates that Hipparchia put the disputa-

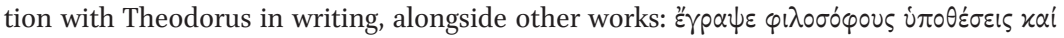

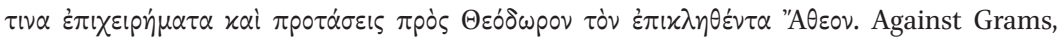
"Hipparchia" (n. 22), 335, Diog. Laert. 6.98 does not mention "letters, jokes and philosophical refutations" written by Hipparchia, only "a book entitled 'letters" and "tragedies" written by Crates. Of Hipparchia, Diogenes only says that many other stories besides that

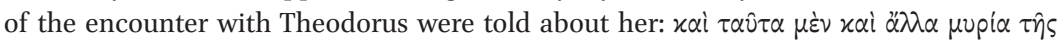

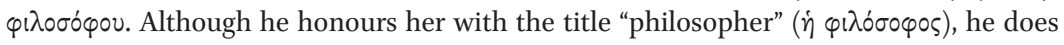
not acknowledge her as an author of philosophical works, only her husband. In contrast, the Suda account suggests that she did write works, but none of them are extant. For further details see García Gonzáles and Fuentes Gonzáles, "Hiparchia de Maronée (n. 22)." 
Diogenes' account has a clear tendency: Hipparchia was a woman who was equal to men including her husband. It was she who chose the man whom she wanted to marry. The marriage was conducted with mutual agreement. ${ }^{31}$ Crates refers to Hipparchia as his (equal) companion. They wore the same clothes and lived the same lives, as Cynic philosophers. This is why Epictetus, who argued (diatr. 3.22.76) that the life of a Cynic was not normally compatible with married life, treats Crates' marriage as a special case, on two grounds: a) It was originally based on épws. The teenage Hipparchia was madly in love with

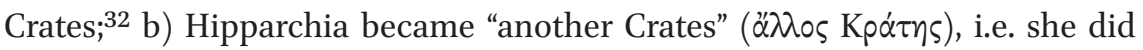
not fulfil the role of a "wife." Neither of these two characteristics apparently applied to what Epictetus would have considered 'normal marriages.' And yet, the relationship between Crates and Hipparchia seems to have been considered a marriage in the proper sense both in their own time and in later Antiquity, albeit qualified by Crates himself as a "Cynics' marriage," a marriage that as such would have breached the conventions of 'normal' marriages in his time but was nevertheless recognisable and in a certain sense 'tolerable,' namely as the typical behaviour of Cynic philosophers (male or female). ${ }^{33}$

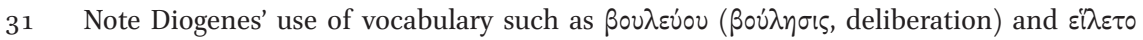

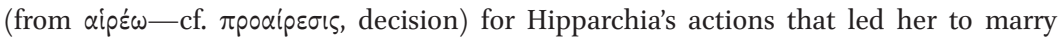
Crates. According to Epict. diatr. 3.22.76 these were not the typical thought processes and actions of women who married.

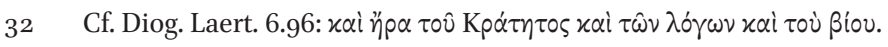

33 The comparison in this paragraph of Crates' and Hipparchia's marriage with 'normal' marriages in their own time and in the times of their doxographers (Diogenes, Epictetus and others cited above n. 23) is here based on a critical reading of the latter. A more thorough social-historical investigation into what constituted a 'normal marriage' in Athens in Crates' and Hipparchia's lifetime or in the times of the cited doxographers is beyond the scope of this article; for further reading see Ch. A. Cox, "Marriage in Ancient Athens," and T. Morgan, "The Socialisation of Children in Education and Beyond," in B. Rawson (ed.), A Companion to Families in the Greek and Roman Worlds (Chichester, 2011), 231-244 and 504-520 at 519 (on Hipparchia's education in view of her marriage to Crates); also useful are S. Treggiari, "Marriage II.: Greece," Brill's New Pauly 8 (2006) 386-388; A. Oepke, "Ehe I. Institutionen," G. Delling, "Eheleben," id., "Eheschließung," RAC 4 (1959) 65o-666 at 651-656, 691-707 at 694-702 and 719-731 at 724-725; and E. Dassmann and G. Schöllgen, "Haus II.: Hausgemeinschaft," RAC 13 (1986) 801-905 at 815-835. J. H. Oakley and R. H. Sinos, The Wedding in Ancient Athens (Madison, WI, 1993) is excellent on (Attic black and red figure) images of weddings; note in this context the well-known depiction of Hipparchia's 'wedding' in a first century AD Roman wall painting from the Garden of the Villa Farnesina, Museo delle Terme, Rome. It depicts Hipparchia holding with her left arm a chest or basket with her belongings on her head while stretching her right arm out to Crates, who is recognisable as a Cynic philosopher by his staff ( $\xi \dot{\lambda} \lambda \circ v)$ and his shoulderbag made of leather $(\pi \dot{n} \rho \alpha)$, two items also mentioned by Tatian in or. 25.1. For further details on this painting and on how Crates' and Hipparchia's marriage reflects typical behaviour 
Seen from this perspective the original connotation of $x v v 0 \gamma \alpha \mu$ í may therefore well have been meliorative. The marital relationship between Crates and Hipparchia fulfilled highest ethical standards shared not only by Cynics but also by representatives of other philosophical schools (e.g. the Stoics, whose founder, Zeno, was thought to have been a pupil of Crates). ${ }^{34}$ There is, however, one aspect, related by Diogenes Laertius, that would have contributed to the pejorative perception of Crates' and Hipparchia's "dog-marriage," even though it was considered by some as a natural aspect of the egalitarian character of the relationship. Diogenes Laertius writes (6.97) that Hipparchia "walked about with her husband, performed the marital act with him in public and also attended dinners with him." 35 The expression used here for "performing the

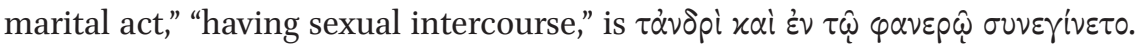
This seems unequivocal. The phrase $\alpha \dot{\alpha} \delta \rho i ~ \sigma u \gamma r i \gamma v \varepsilon \sigma \theta \alpha \iota$ can be understood as a woman having sex with a man. ${ }^{36}$ What about $\varepsilon \nu \tau \hat{\omega} \varphi \alpha \nu \varepsilon p \hat{\varphi}$ ? Could this not simply mean that they showed themselves in public as a married couple? Most ancient sources seem to suggest that it means more than that. Sext. Emp. Pyrrh. hyp. 1.153, for example, argues that while other couples performed the marital act behind closed doors ( $\dot{\alpha} \vee \alpha \omega \omega \rho 0 \hat{v} \tau \varepsilon \varsigma)$ Crates and Hipparchia did it openly, in public $(\delta \eta \mu o \sigma i \alpha)$. Clem. Alex. strom. 4.19.121.6 is even more specific and names the precise location, the painted porch $(\sigma \tau \circ \dot{\alpha} \pi \circ x i \lambda \eta)$ on the northern edge of the Athenian Agora that gave its name to the philosophical school founded by

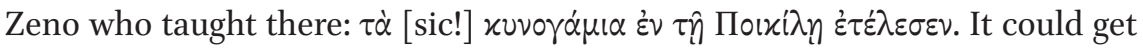
hardly more public than that, although Lact. div. inst. 3.15.20 goes yet further treating the report as relating to a general custom among Cynics (and duly protesting moral outrage): nam quid ego de Cynicis loquar, quibus in propatulo coire cum coniugibus mos fuit? While earlier, non-Christian, sources tended to represent the anecdote as a case of exceptional, individual, even symbolic, behaviour, a Christian polemicist such as Lactantius treated it as an abomination that characterised an entire culture. In his account the act was not carried out in the partly covered space of a porch but potentially entirely out in the open air (in propatulo) thus evoking the image of mating animals.

of Cynic philosophers, D. Clay, "Picturing Diogenes," in Bracht Branham and Goulet-Cazé, The Cynics (n. 13), 366-388 at 372-373.

34 Diog. Laert. 7.1-4; see also below the reference to Apul. flor. 14., and above n. 23.

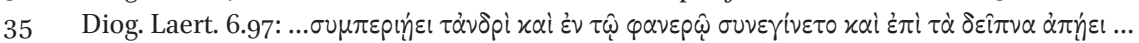
The Dative $\alpha \dot{v} \delta$ i can be understood to refer to all three activities. Some older translations prefer to translate the middle clause as Hipparchia "being openly together with her husband," i.e. showing herself together with him. This is grammatically correct but fails to do justice to the provocative content of the sentence.

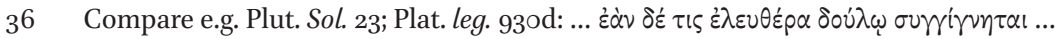


In contrast with this tendency in Christian polemics increasingly to exaggerate the original report, later non-Christian reports tried to tone down the scandalous nature of Crates' und Hipparchia's behaviour. Apul. flor. 14, for example, concedes that Crates, in response to Hipparchia's call to take her wherever he pleased (proinde duceret quo liberet) led her to the porch to have sex with her there in open daylight (ibidem, in loco celebri, coram luce clarissima accubuit). But, he continues, Crates' pupil Zeno held up his cloak (palliastri) to protect his teacher's privacy (magistri secretum) as well as that of his equally keen (pari constantia) lover. Thus, according to Apuleius - in contrast to what Lactantius suggested - the act was far from being mos, even among Cynics. It was exceptional, highly sensitive and constituted but one aspect of an entire programme of a public philosophical life, i.e. the equal marital partnership of Crates and Hipparchia. ${ }^{37}$

Considering Hipparchia's importance in this partnership it is noteworthy

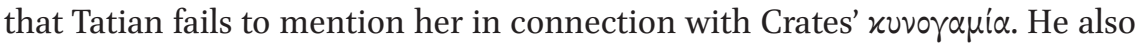
fails to elaborate on one of the more notorious aspects of the latter, the couple's public consummation of the marriage, which is otherwise widely attested. By asking rhetorically who wanted to be a witness at that wedding he clearly distances himself from a meliorative interpretation of the couple's act, as can be expected from a Christian polemicist, especially one that had the (albeit doubtful) reputation in his time and shortly after of being a leading Encratite, one who rejected marriage altogether. ${ }^{38}$ Could that perhaps have been a rea-

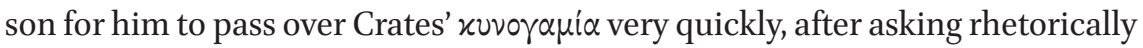
who would be a witness at that wedding, thereby stating categorically that he certainly would not? But let us now turn to the second part of the three-part

37 This is especially underlined by Diogenes Laertius' account (6.97; see above n. 35), who mentioned the marital act as a matter of course alongside walking about together in public and attending banquets.

38 See Iren. haer. 1.28.1 apud Euseb. h. e. 4.29.2 and Clem. Alex. strom. 3.12.81.1-2, noted above n. 25. While these early accounts speak of Tatian as a vociferous follower of the newly emerged sect of the Encratites, later accounts see in him the founder, or at least the leading figure (heresiarch), of Encratism. It is Eusebius, h. e. 4.28-29, who first reports that Encratism only emerged in Tatian's own time and that Tatian himself is thought to

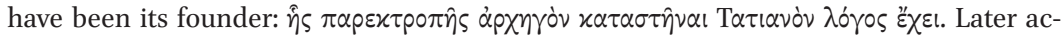
counts (Jerome, Epiphanius) probably followed Eusebius' assessment; cf. e.g. Jerome, in Amos 2.12: T. Encratitarum princeps; in ep. ad Tit. praef:: T. Encratitarum patriarches; in ep. ad Gal. 6.8: T. Encratitarum acerrimus haeresiarches; further references are listed by Trelenberg, Tatianos (n. 9), 7 n. 38; on Tatian's Encratism in the wider context of early Christian attitudes to sex and marriage see D. Weisser, Quis maritus salvetur? Untersuchungen zur Radikalisierung des Jungfräulichkeitsideals im 4. Jahrhundert (Berlin \& New York, 2016), 193-201. 
interrogative sentence of which or. 3.6 is made up, the equally rhetorical question who would not rather (than witnessing Crates' zovorapia) reject the presumptuous "tongue madness" ( $\gamma \lambda \omega \sigma \sigma o \mu \alpha v i \alpha)$ of those who are like Crates $(\tau \omega \hat{\omega} \nu$ $\left.\delta \mu \delta^{i} \omega \nu \alpha \dot{\tau} \tau \hat{\omega}\right)$.

Let us begin this section with a graphic display of the entire sentence (or. 3.6) in order to appreciate better its elements of parallelism and prose rhythm, with similar endings that have a hint of homoioteleuton. The effect would have been stronger orally than it may look in writing, but even the written sentence reveals some remarkable features:

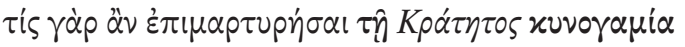

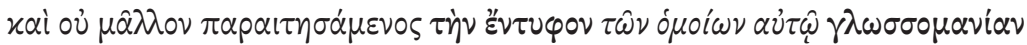

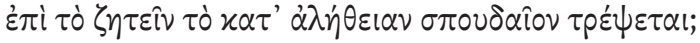

A look at the entire structure shows that the first two lines are building up a tension that is resolved in the third line: "Who would ... and who would not rather ... in order to ...?" The tension is increased in the second line, which is at least a third longer than the first. A number of elements are added and

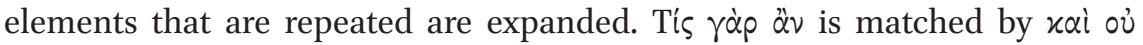
$\mu \hat{\alpha} \lambda$ ov ...; $\mu \hat{\alpha} \lambda$ ov is a new, additional, element. As a comparative form and an

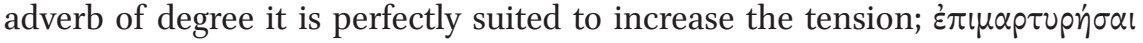
and $\pi \alpha p \alpha \iota \tau \eta \sigma \alpha \mu \varepsilon v o s$ form a parallel construction, though not quite. The weak Aorist element - $\eta \sigma \alpha$ - offers a hint of parallelism, but the prefix $\dot{\varepsilon} \pi-$ gives way to a more aggressive $\pi \alpha p$ - while the monosyllabic active infinitive ending $-\alpha \mathrm{l}$ is matched by the more forward-thrusting, dynamic, two-syllable middle par-

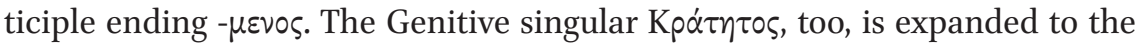
Genitive plural cum Dative singular $\tau \hat{\omega} v \dot{\delta} \mu \operatorname{i}^{\prime} \omega \nu \alpha \dot{\nu} \tau \hat{\omega}$, and the more static and

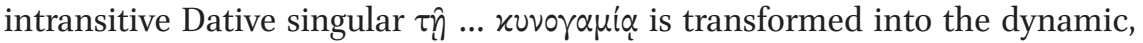
transitive, Accusative $\tau \dot{\eta} \nu$ है $v \tau \cup \varphi \circ \nu . . . \gamma \lambda \omega \sigma \sigma \sigma \mu \alpha v^{\prime} \alpha \nu$, which is expanded by a

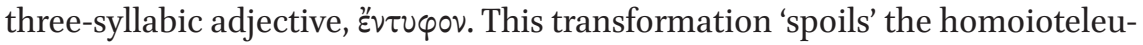
ton: The first line ending $-\alpha$ is matched by $-\alpha \nu$ in the second line. But this $-\alpha \nu$ drives the whole sentence forward to its conclusion and resolution. Note that

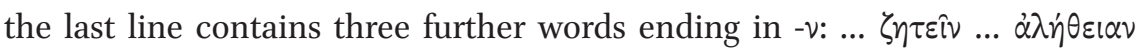

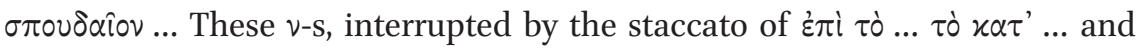
resolved by the final, rhythmic, $\tau \rho \varepsilon \varepsilon-\varepsilon-\tau \alpha$, are somehow picking up the baton from $\gamma \lambda \omega \sigma \sigma o \mu \alpha \nu i-\alpha \nu$ in the previous, second, line. 
There can be no doubt that $x v v o \gamma \alpha \mu i \alpha$ and $\gamma \lambda \omega \sigma \sigma o \mu \alpha v^{\prime} \alpha$ are the two key words in the sentence. The first is associated with the person of Crates

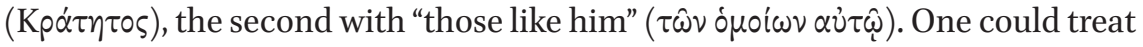
this latter phrase as a manner of speaking referring to Cynics, or simply hypothetically to anyone who speaks in a mad way as Crates did, if this is what $\gamma \lambda \omega \sigma \sigma o \mu \alpha v i \alpha$ is referring to, speaking in a mad way. But in what way did Crates speak madly? And why is Tatian widening his scope and implicating "those who are like" Crates? Whom might he have thought of? Earlier in the first section we saw that behind the word $x$ vvorapia Tatian may have been hiding the figure of Hipparchia and all that she stood for. Might it be possible that the word $\gamma \lambda \omega \sigma \sigma o \mu \alpha v i \alpha$ is linked to her as well? To answer this question let us first explore the meaning and context of $\gamma \lambda \omega \sigma \sigma o \mu \alpha v^{\prime} \alpha$.

Or. 3.6 is the only passage in ancient Greek literature where we can find the word $\gamma \lambda \omega \sigma \sigma o \mu \alpha v^{\prime} \alpha{ }^{39}$ It literally translates as "madness of the tongue," meaning (probably) "mad talk" or "speech." This could refer either to the content of what is said or to the manner of delivery. As discussed earlier, in the wider context of or. 3 the word occurs in a list of words that denote the arrogance and stupidity of ancient Greek philosophers generally, e.g. $\alpha \lambda \alpha \zeta o v \varepsilon i \alpha$ and $\alpha \mu \alpha \theta^{\prime} \alpha$ and related forms. ${ }^{40}$ But here in or. 3.6 stupidity and self-important arrogance

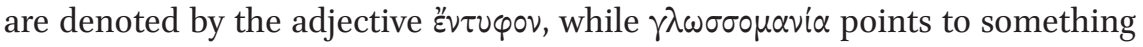
else, something that is meant to be typical for Cynics generally and for Crates (or for Crates and Hipparchia) in particular; a 'vice' perhaps, as, e.g., Plato's

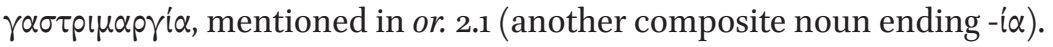

Irrational, 'crazy', behaviour or (performed!) 'madness' tended to be a trademark of Cynics. Diog. Laert. 6.88-91 relates several instances of such behaviour as displayed by Crates such as wearing a heavy woollen cloak in the heat of summer and flimsy rags in winter or throwing his money into the sea. Crates was also known for engaging people in upsetting conversations, infuriating them and even provoking some of them to resort to violent acts against him, such as the cithara-player and singer Nicodromus, who after a particularly exasperating conversation punched him in the face. ${ }^{41}$ Hipparchia's caustic encounter with Theodorus the Atheist followed a similar pattern: A woman dressed in men's clothing attending a symposium and confronting a man who was himself a well-known provocateur with a twisted, on the face of it not very

39 This verdict is based on a lemma search in the TLG database. The word cannot be found in either LSJ or Lampe (A Patristic Greek Lexicon).

40 See above n. 7 .

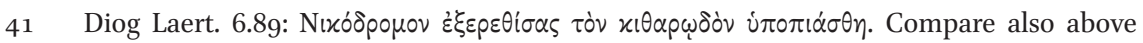
n. 27 the example of Crates provoking prostitutes through invective and then 'practising'

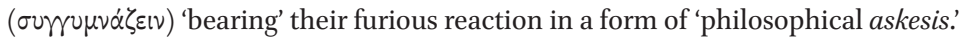


substantive but provocative and even aggressive sophism, to which Theodorus could not respond but by pulling up her outer garment. ${ }^{42}$

But one may doubt whether in Tatian's or. 3.6, with a view to Crates and Hipparchia, $\gamma \lambda \omega \sigma \sigma o \mu \alpha v i \alpha$ was really aimed at this kind of Cynic sophistry, which was, after all, in many respects highly rational. Both components of the noun, $\gamma \lambda \hat{\omega} \sigma \sigma \alpha$ and $\mu \alpha v i \alpha$, point in several other directions. Compounds involving $\gamma \lambda \hat{\omega} \sigma \sigma \alpha$ are rare. A scholion to Soph. Oed. Tyrr. 634-5 explains the expres-

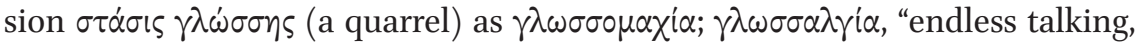
wordiness," is relatively frequent in the TLG (ca. 250x); $\gamma \lambda \omega \tau \tau \alpha \rho \gamma i \alpha$, "idleness of the tongue, blasphemy," less so. $\Gamma \lambda \omega \sigma \sigma o \delta \delta \varepsilon \mu$ is a paralysis of the tongue; $\gamma \lambda \omega \sigma \sigma \alpha \lambda \lambda \alpha \gamma \dot{\eta}$, in Apoc. Baruch 3.8.2, a confusion of tongues.

Combinations with - $\mu \alpha v i \alpha$ generally imply loss of rationality, a slip into what is also in English known as "mania." Compounds are relatively frequent and

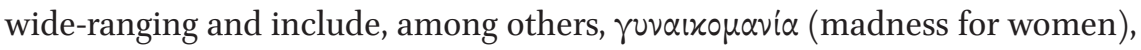
$\gamma \varepsilon p o v \tau o \mu \alpha v^{\prime} \alpha$ (the craze or dotage of old men; title of a play by Anaxandrides;

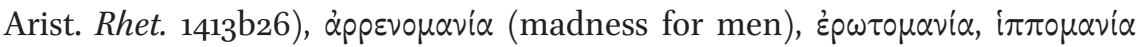

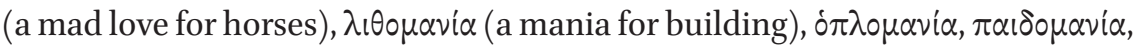

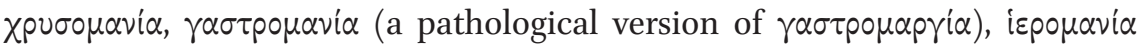

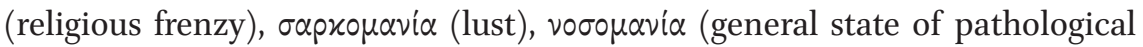

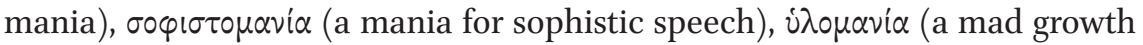

According to Diog. Laert. 6.97-98 Hipparchia's sophism went as follows: An act that could not be called wrong in Theodorus' case could not be called wrong in Hipparchia's case either. Now it could not be wrong for Theodorus to hit himself. Thus, neither could it be wrong for Hipparchia to hit Theodorus. Theodorus had nothing to say in reply but pulled

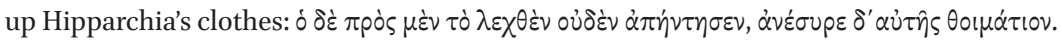

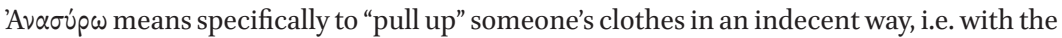
intention to expose the other person. As Grams, "Hipparchia" (n. 22), 345-349 points out, already the premise of the syllogism is charged and would have been controversial at the time. For in reality, women were not allowed to do the same things as men. Furthermore, the implication of the conclusion is that self and other are equivalent regardless of sex (a variation on the Golden Rule?). Theodorus' reaction could therefore be interpreted as a performative act (thus Grams, ibid.): If it is right for Hipparchia herself to loosen her dress, then it cannot be wrong for Theodorus to do so either. Perhaps Hipparchia, too, had earlier concluded her syllogism with a performative act and hit Theodorus. But such

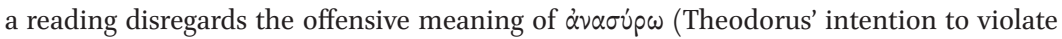
Hipparchia — or is the implication here that by being, and acting as, a Cynic philosopher Hipparchia is violating herself, or that Theodorus and Hipparchia are jesting?) and the

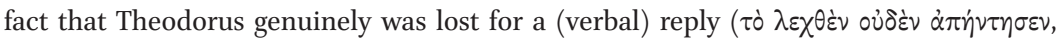
from $\dot{\alpha} \pi \alpha \nu \tau \dot{\alpha} \omega$, "to come up with sth."). What is also interesting in this context is that according to Diog. Laert. 2.86 Theodorus was a pupil of Aristippus the Younger, who was trained in philosophy by his mother Arete, daughter of Aristippus the Elder (on whom see also above the comments on Tatian, or. 2.1). The (admittedly rare) phenomenon of women philosophers would therefore not have been entirely unfamiliar to Theodorus. 
of wood), $\chi \varepsilon \rho \sigma o \mu \alpha v^{\prime} \alpha, \psi \varepsilon v \delta \delta \mu \alpha v^{\prime} \alpha$ (compulsive lying), $\chi p ı \tau \tau o \mu \alpha v^{\prime} \alpha$ (fury against

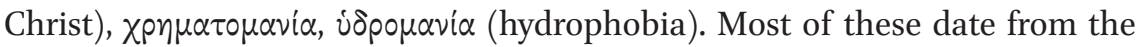

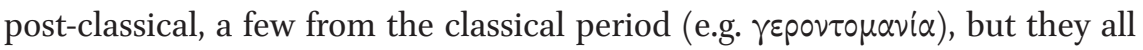
outline the same semantic range of irrational, "manic," behaviour.

In Hipparchia's case the boundaries of rationality were first breached by what Diog. Laert. 6.96-98 depicts as her "mad love" for Crates and his philosophy. ${ }^{43}$ Yet there is a dialectic here. Hipparchia's madness - and what conventional etiquette in her time may have perceived as such — consisted in her rational philosophical pursuit of equality with her husband (opoios a $\left.\tau_{\tau} \hat{\omega}\right)$,

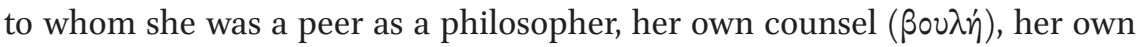

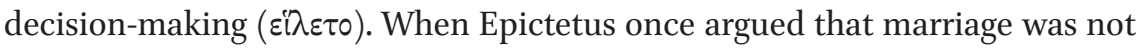
an option for philosophers and was confronted with the example of Crates

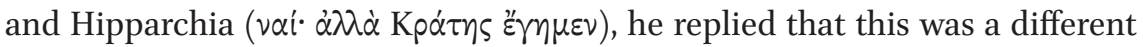

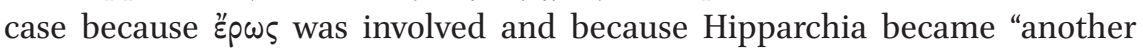

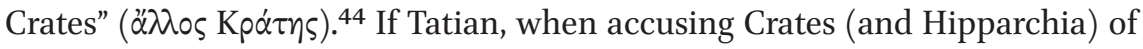
some kind of $\mu \alpha v^{\prime} \alpha$, was thinking of this aspect of their philosophy, then this may also go some way to explain the third line of or. 3.6 (as cited above), the "pursuit of what is truly worth pursuing," what is "truly serious." For by this he means that which transcends the level of the individual human being and of humanity generally. This is where he rejects a humanism that is celebrating the ordinariness of human life and criticizing and subverting attempts at denying this reality by creating differences, hierarchies, boundaries, and ideologies justifying the latter. In other words, this is where he outs himself, albeit dimly, as a proto-orthodox Christian Platonist. ${ }^{45}$

To pursue this latter aspect in a final reflection in this article, let us look briefly at the religious dimension of $\mu \alpha v^{\prime} \alpha$. It was Christopher Forbes who some time ago drew a link between Hipparchia's "erotic" (= है $\rho \omega \varsigma$-motivated) approach to philosophy (according to Epict. diatr. 3.22.76) and women (e.g. in early Christianity) driven by a divine $\mu \alpha v i \alpha$ to prophecy and related forms of religious expression, ${ }^{46}$ some of whom also assumed roles of religious leadership. ${ }^{47}$ As Forbes points out, these women were able to do such things by virtue of this $\mu \alpha v^{\prime} \alpha$, the effects of which imbued them with religious authority.

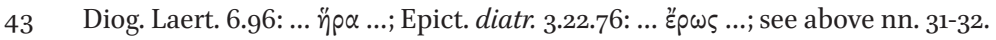

44 Epict. diatr. 3.22.76.

45 Cf. above n. 17 on Elze, Tatian (n. 17); see also Trelenberg, Tatianos (n. 9), 31-34. 43-45. 51-6o.

46 Including 'philosophical' teaching in public, authoring and circulating written works, or "speaking in tongues" or "in foreign tongues" (on which more below).

47 See C. Forbes, Prophecy and Inspired Speech in Early Christianity and its Hellenistic Environment (Tübingen, 1995), 141 n. 43.
} 
Yet at the same time their manic behaviour was also accepted as a factor that diminished their responsibility. Behaviour was tolerated and even venerated (at least by their followers) that would otherwise have been suppressed and sanctioned. ${ }^{48}$

We know that Tatian took a dim view of this type of Christian women's spirituality. To be sure, in or. 33.4 he does speak of "women among us who

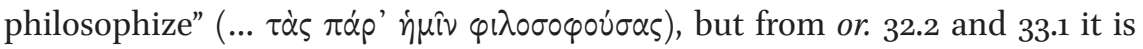
fairly clear that by this he means mainly poor people ( $\pi \dot{\varepsilon} v \eta \tau \varepsilon \varsigma)$ who enjoy

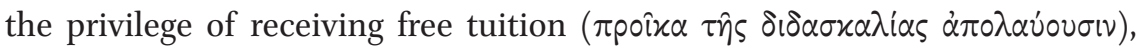

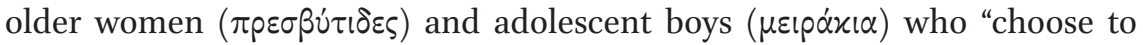

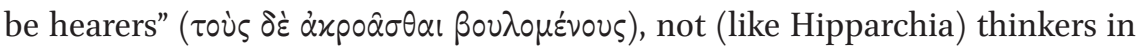
their own right. Tatian even concedes that his enemies accuse him of "talking nonsense to women, adolescent boys, young women and old women"

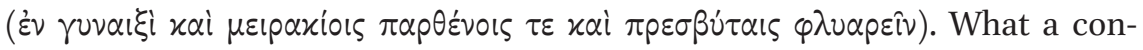
trast to Hipparchia's behaviour outlined earlier, or to the exploits of charismatic prophetic Christian women in Tatian's own time ${ }^{49}$ such as, for example,

48 Forbes (ibid.) cites here as an example Hipparchia's behaviour, which was excused by Epict. diatr. 3.22.76: What was not acceptable in the case of other married women was acceptable in her case because of her हैpw for Crates and philosophy. She was counted as a married woman, even though her behaviour fell well short of what was conventionally expected of married women. Perhaps there is an analogy here to the early Christian case of Priscilla who on account of her prophetic role was counted as a virgin even though she had been married. Euseb. h. e. 5.18.3 reports that she and Maximilla left their husbands

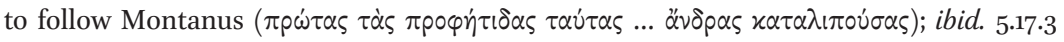
her and her followers' claim to her virginity is challenged: $\pi \hat{\omega} \varsigma$ oûv $\dot{\varepsilon} \psi \varepsilon \dot{\delta} \delta 0 v \tau 0 ~ \Pi p i \sigma x \curlywedge \lambda \alpha \nu$

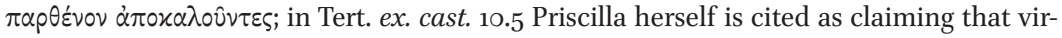
ginity is purity achieved through ascetic austerity. But such a claim was open to challenge. Elsewhere Tertullian draws a clear distinction between wives, widows and virgins (virg. vel. 4). Euseb. h. e. 5.17.3, too, gives the impression that referring to Priscilla as a virgin was not universally seen as acceptable or justifiable among Christians. Obviously, by referring to her/self as $\pi \alpha p \theta$ Évos (despite her being a married wife) Priscilla and her followers claimed exceptional status for her/self. V.-E. Hirschmann, Horrenda Secta. Untersuchungen zum frühchristlichen Montanismus und seinen Verbindungen zur paganen Religion Phrygiens (Stuttgart, 2005), 99-119 raises the possibility that in doing so they could have been influenced by non-Christian religious cult-traditions predominant in the region (Phrygia), in which older prophetic women who had been or were still married were addressed as $\pi \alpha p \theta \varepsilon v$ vo on account of their prophetic roles; though see the critical response by Chr. Markschies, "Montanismus," RAC 24 (2012) 1197-1220.

49 There is even an uncanny proximity in Euseb. chron. Hier. an. 171-172 (206 Helm) between the beginning of Montanism in 171 and Tatian's move to the East in 172: pseudoprofetia quae cata frygas nominator accepit exordium auctore Montano et Priscilla Maximillaque insanis vatibus. 172: Tatianus haereticus agnoscitur a quo encratitae. For alternative datings see Hirschmann, Horrenda Secta (n. 48) 43; the dating given ibid. for Eusebius' chronicle (172) is incorrect. Apollonius' polemic extant in Euseb. h. e. 5.16 and 18 dates from 175 
Priscilla and Maximilla, who became companions of an ecstatic prophet and founder of a religious movement, Montanus, ${ }^{50}$ delivered their teaching and pronounced their prophecies in public, authored and published written works under their own name, ${ }^{51}$ commanded a considerable following and exercised authority engaging with other church leaders in controversial discussions and negotiations, ${ }^{52}$ all the while possessing enough means to enjoy an upscale lifestyle, scandalous in the eyes of their detractors, ${ }^{53}$ notwithstanding the fact that

(see ibid. 5.18). Maximilla's death is dated 179 (ibid. 5.16.19). A link between the origin of Montanism and Encratism is also drawn by Epiphan. Pan. 48.1.1-2, according to whose chronological note ("nineteenth year of ... Antoninus Pius") Montanism began in 156 or 157. I. Ramelli, "Tracce di Montanismo nel Peregrinus di Luciano?" Aevum 79 (2005) 79-94 suggests an even earlier date for the beginnings of Montanism (in the 140s?). For a summary overview on the chronology of Montanism see Markschies, "Montanismus (n. 48)."

50 Among its opponents the movement was variously referred to as "Montanism," "Priscillianism" or "Cataphrygian Heresy," while for its adherents it was "the new prophecy" ( $(\varepsilon \dot{\varepsilon} \alpha \pi \rho \circ \varphi \eta \tau i \dot{\alpha} \alpha$; see Euseb. h. e. 5.19.2). A main source is Euseb. h. e. 5.16-19. The exact relationship between Montanus and the two women prophets is complex and will not be discussed here. Main studies include Hirschmann, Horrenda Secta (n. 48), especially $5^{2}$ (on the relationship between Montanus, Priscilla and Maximilla); C. Trevett, Montanism. Gender, Authority and the New Prophecy (Cambridge, 1996), 151-154 (focusing on Priscilla and Maximilla); A. Marjanen, "Montanism: Egalitarian Ecstatic 'New Prophecy," in A. Marjanen and P. Luomanen (eds.), A Companion to Second-Century Christian 'Heretics' (Leiden, 2005), 185-212 at 188-189 and 207-208; W. Tabbernee, Fake Prophecy and Polluted Sacraments: Ecclesiastical and Imperial Reactions to Montanism (Leiden, 2007); W. Tabbernee and P. Lampe, Pepouza and Tymion (Berlin and New York, 2008); H. E. Mader, Montanistische Orakel und kirchliche Opposition (Göttingen, 2012) and Markschies, "Montanismus (n. 48)," who also lists further literature.

51 In the discussion between a Montanist and an orthodox Christian known as Dialexis the orthodox interlocutor criticizes the women prophets for publicly teaching and having published works under their own names thereby assuming for themselves "authority

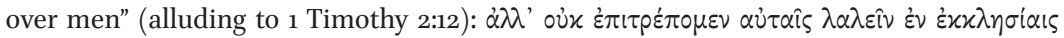

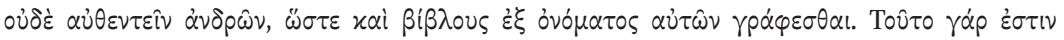

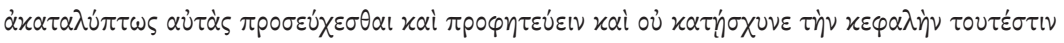

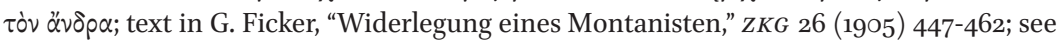
also R. E. Heine, The Montanist Oracles and Testimonia (Macon, GA, 1989), 112-126. Didym. Trin. 3.41 (PG 39: 988.47) makes the same point with regard to what he considers good

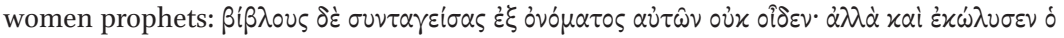

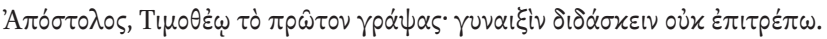

52 Euseb. h. e. 5.18.13 relates the scenario of what seems to have been basically a public disputation, in which a prophesying Maximilla was challenged by an opponent and supported by her followers.

53 Euseb. h. e. 5.18.4, 6 and 11 suggests that at least one of the two women continued wearing luxury clothes and precious jewellery, hosting lavish banquets and putting on make-up. Hier. ep. 133.4 refers to both women as nobiles et opulentes feminae. Compare now also S. Mitchell, "An Epigraphic Probe into the Origins of Montanism," in P. Thonemann (ed.), Roman Phrygia: Culture and Society (Cambridge, 2013), 168-197 at 191-192. 
their authority was grounded in the authenticity and credibility of an austere ascetic and prophetic way of life.

If we assume on the basis of what has just been outlined that Tatian was not greatly in favour of the way in which Montanism enhanced the authority of prophetic women such as Priscilla and Maximilla, it is at least possible that by speaking in or. 3.6 of the $\gamma \lambda \omega \sigma \sigma o \mu \alpha v^{\prime} \alpha$ of Crates and others "like him," Tatian, when using this expression, $\tau \hat{\omega} \nu \delta \mu \delta^{\prime} \omega \nu \alpha \dot{\tau} \tau \hat{\omega}$, was not only thinking of other Cynics, or of Hipparchia, Crates' wife, but of early Christians, contemporaries, women in particular, who prophesied and engaged in what is known in connection with certain early Christian phenomena known from the sources as $\gamma \lambda \omega \sigma \sigma 0 \lambda \alpha \lambda i \alpha$, "speaking in tongues," 54 with a variant of this being known as $\xi \varepsilon v 0 \lambda \alpha \lambda i \alpha$ or $\xi \varepsilon v \sigma \gamma \lambda \omega \sigma \sigma i \alpha$, "speaking in foreign tongues." 55 Contemporaries of Tatian's such as Irenaeus tended to acknowledge the spiritual authenticity of such phenomena. ${ }^{56}$ But there was also criticism, rejection and, eventually, suppression of activities such as those performed by women such as Priscilla and Maximilla.

Forbes has warned not to confuse Montanist prophetic speech with $\gamma \lambda \omega \sigma \sigma 0 \lambda \alpha \lambda i \alpha$ and William Tabbernee has endorsed this view. ${ }^{57}$ This would be fine and well if there were a generally accepted definition of $\gamma \lambda \omega \sigma \sigma 0 \lambda \alpha \lambda i \alpha$. The argument that unlike $\gamma \lambda \omega \sigma \sigma o \lambda \alpha \lambda i \alpha$ plain prophetic speech does not require interpretation is misleading. Any prophecy only comes to fruition in an interpretive process so much so that some in Christian antiquity have argued

54 Cf. e.g. 1 Corinthians 12:30: $\pi \dot{\alpha} \nu \tau \varepsilon \varsigma ~ \gamma \lambda \omega \dot{\omega} \sigma \sigma \alpha \iota \varsigma ~ \lambda \alpha \lambda \circ v 0 \sigma \nu$ (similarly 1 Corinthians 13:1, 14:5-6,

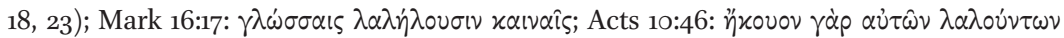

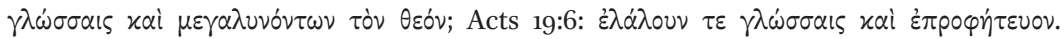
According to G. Strohmaier, "Lukian verspottet die urchristliche Glossolalie: ein rätselhafter Satz in Galens Epidemienkommentaren," Philologus 156 (2012) 166-173, Lucian of Samosata, in a recently discovered fragment extant in Arabic, mocked early Christians for engaging in the practice. But note that J. N. Bremmer, "Lucian on Peregrinus and Alexander of Abonouteichos: A sceptical view of two religious entrepreneurs," in R. L. Gordon, J. Petridou and J. Rüpke (eds.), Beyond Priesthood: Religious Entrepreneurs and Innovators in the Roman Empire (Berlin and New York, 2017), 49-78 at $5^{2} \mathrm{n} .2 \mathrm{O}$ is sceptical about this and points to an alternative interpretation. See ibid. also on the "very early history" of Montanism (compare above n. 49). All these possible links also raise intriguing possibilities regarding a link between Tatian and Montanism. But the challenge in this regard is the same as that cited by Bremmer (ibid.) for Montanism: a lack of sources.

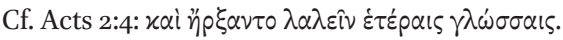

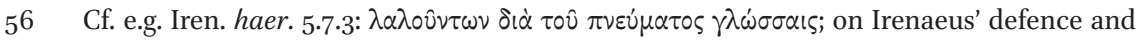
even advocacy of the new prophecy see Hirschmann, Horrenda Secta (n. 48), 45; more cautiously, Tabbernee, Fake Prophecy (n. 50), 34-36.

See Forbes, Prophecy (n. 47), 16o-162; Tabbernee, Fake Prophecy (n. 5o), 95-10o. 
that the real prophecy is in the exegesis. ${ }^{58}$ Vice versa, any prophecy, even one delivered in plain speech, involves an element of ecstasy, i.e. divine $\mu \alpha v i \alpha$. That is the nature of prophecy. ${ }^{59}$ Prophecy that is not delivered in plain comprehensible speech, therefore, cannot be explained entirely with a reference to linguistic circumstances, e.g. the fact that a prophet comes from a linguistic community other than those to whom the prophecy is addressed. In terms of textual study this is of course important, but it cannot provide a final and full explanation of a particular phenomenon. ${ }^{60}$

The sources that describe Priscilla's and Maximilla's prophetic speech are at pains to emphasize its ecstatic character. One can almost get the impression that they protest too much. E.g. Eusebius, h. e. 5.16.9 characterises their

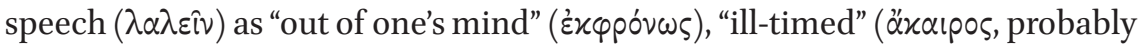

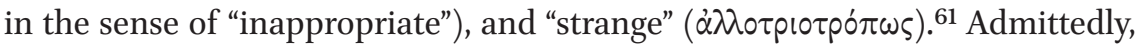
this is a polemical source. It stipulates that the two women who utter these

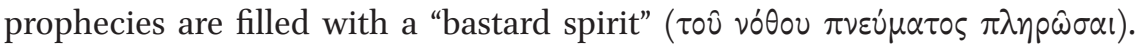
But the point is: The prophecies are spirit-induced and ecstatic. Earlier (ibid. 5.16.7) Montanus' prophecy had been similarly characterised: "inspired"

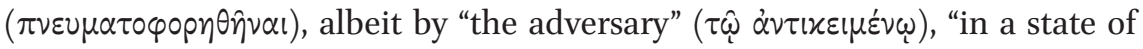

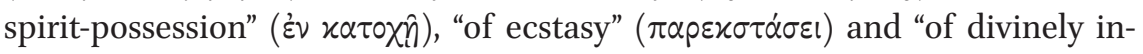
spired ecstasy" ( $\dot{\varepsilon} v \theta 0 v \sigma i \hat{\alpha} v)$. Thus Montanus "began to speak and to sound as

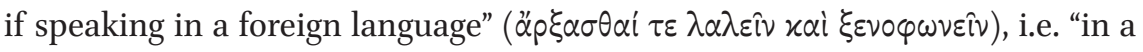

$5^{8}$ This was my argument in J. Lössl, "Poets, Prophets, Critics, and Exegetes in Classical and Biblical Antiquity and Early Christianity," JLARC 1 (2007) 1-16; repr. as id., "Poetry, Prophecy and Criticism in Classical and Patristic Exegesis," Aug. 48 (2008) 345-367.

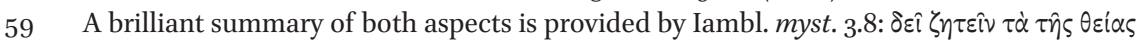

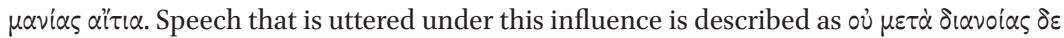

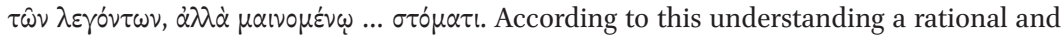
an irrational element are at work in the prophetic process. Replace $\sigma \tau \dot{\alpha} \mu \alpha$ with $\gamma \lambda \omega \dot{\omega} \sigma \sigma \alpha$ and we arrive at Tatian's $\gamma \lambda \omega \sigma \sigma o \mu \alpha v i \alpha$.

6o For the case of Montanism C. Brixhe, "Interactions between Greek and Phrygian under the Roman Empire," in J. Adams, M. Janse and S. Swain (eds.), Bilingualism in Ancient Society. Language Contact and the Written Text (Oxford, 2002), 247-266 offers helpful thoughts in this regard. As illustrated above by the references to $\mathrm{nn} .54$ and 55 the sources do not strictly distinguish between 'pure' $\gamma \lambda \omega \sigma \sigma 0 \lambda \alpha \lambda i \alpha$ (i.e. inarticulate spiritual utterings that are not linguistically classifiable) and $\xi \varepsilon v 0 \lambda \alpha \lambda i \alpha$ or $\xi \varepsilon v \sigma \gamma \lambda \omega \sigma \sigma i \alpha$ (i.e. spirit-infused speech involving 'foreign' language elements).

61 M. Tardieu, "Les Lamelles d'Or Montanistes et Orphiques," in M. Tardieu, A. van den Kerchove and M. Zago (eds.), Noms Barbares I: Formes et contextes d'un pratique magique

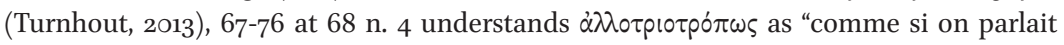
une langue étrangère." Importantly, the emphasis here would have to be on "comme:" These prophecies may have sounded "as if" a foreign language was spoken. But it is not

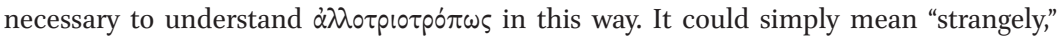
"in a strange manner" (thus Lampe, A Patristic Greek Lexicon). 
manner foreign to tradition and to the succession of the church from the be-

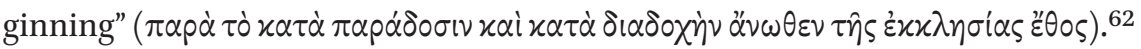

The pleonasm in which the source describes Montanus', Priscilla's and Maximilla's prophetic activity uses words that are usually associated with traditional, non-Christian forms of "divine mania." ${ }^{33}$ As the ending of the above cited passage from Eusebius, h. e. 5.16.7 may indicate, Christian 'traditionalists,' who in the 170s would have been getting used to 'orderly' hierarchical structures, would have rejected such expressions of what might be called, using a

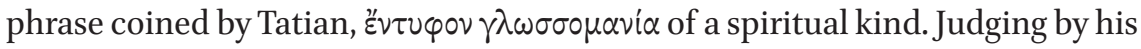
own account in or. Tatian would probably have agreed, notwithstanding the fact that - for different reasons - he himself had fallen foul of the hierarchical order of his church.

Obviously, in Tatian's or. $3.6 \gamma \lambda \omega \sigma \sigma o \mu \alpha v i \alpha$ is used in the very specific context of the philosophy of Crates and of "those like him." However, the lack of any wider context of this hapax legomenon has hopefully justified the above more extensive reflections in the direction of Crates' association with Hipparchia and her philosophy and of the activities - in terms of ecstatic prophecy and, emerging from it, religious leadership—of Tatian's Christian contemporaries Priscilla and Maximilla.

\section{$4 \quad$ Summary and Conclusion}

The purpose of this article is to contribute to a better understanding of Tatian's or. 3.6, in particular of the two key expressions in this sentence, zovorapia and $\gamma \lambda \omega \sigma \sigma o \mu \alpha v i \alpha$. The article began by situating or. 3.6 in the context of Tatian's invective-in the form of a list-against twelve ancient Greek philosophers in or. 2.1-3.7, their philosophical errors as well as their personal faults, above all their stupid arrogance, which according to Tatian they all had in common. The article then turned to the expression vvo $\alpha \mu i \alpha$ and its specific meaning with regard to the marital relationship between the two Cynic philosophers Crates of Thebes and Hipparchia of Maroneia, to which Tatian refers in or. 3.6, however without mentioning Hipparchia by name. The fact was also discussed that the predominant manuscript reading of the relevant noun in or. 3.6 is not

62 Euseb. h. e. 5.17.4-5 further specifies that because of its ecstatic characteristics Priscilla's and Maximilla's prophecy cannot rank alongside that of other, revered, early Christian women prophets, e.g. Ammia or the four daughters of Philip; further details in Hirschmann, Horrenda Secta (n. 48), 108-109.

63 On this extensively Hirschmann, Horrenda Secta (n. 48), 54-73 and 86-120 (passim). 


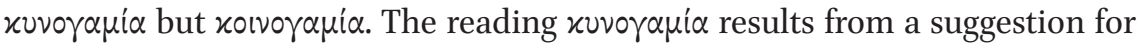
an emendation made by the editor William Worth as late as 1700 . Worth also first drew attention to the role of Hipparchia in this context thus implicitly raising the question why Tatian may have failed to mention her. If xovvorauia were the authentic reading, this question would be less relevant. Tatian's negativity as expressed in his rhetorical question ("who wants to witness...?") would be understandable for either reading, $x$ vvo $\alpha \mu$ i $\alpha$ ("a dogs' marriage, a marriage in the manner of dogs, or a marriage of Cynics") and xovvorapia ("a shared marriage"). The article also discusses this aspect in light of Tatian's alleged association with Encratism, a movement that rejected any form of marriage.

The article then discusses the expression $\gamma \lambda \omega \sigma \sigma o \mu \alpha v i \alpha$. The relevant section begins with a literary-rhetorical analysis of or. 3.6. The word $\gamma \lambda \omega \sigma \sigma o \mu \alpha v^{\prime} \alpha$ is then discussed, first in connection with Hipparchia and her thought, especially aspects of emotionality, irrationality and $\tilde{e} p \omega \varsigma$, which were already noted in Antiquity and could have exposed Hipparchia to the 'charge' of a 'manic' approach to philosophy. Secondly, a closer look is taken at expressions of 'mania' in Tatian's more immediate context of second-century Christianity, for example in the phenomenon of ecstatic women prophets in Montanism such as Priscilla and Maximilla, whose similarity with Hipparchia lies less in what they stand for in religious terms than in what they represent as independently acting women within their social, cultural and political contexts.

Finally, a note of caution: The purpose of this article was not to make second guesses about any 'deeper' thoughts or intentions Tatian might have had when writing or. 3.6. The sentence is simple and plain enough. It refers to what it says. The above notes are only intended to improve our understanding of some of the words and phrases used in that sentence. Still, when looking at the sentence in the wider context of Tatian's own work (the entirety of or.), the historical context in which Tatian wrote (second-century Christianity), and the context of the person he wrote about (Crates), two points may be reiterated one more time (without elaborating once more on their deeper implications): 1) In spite of mentioning Crates' marriage Tatian did not include Hipparchia's name; and 2) to characterise Crates' philosophy Tatian chose a unique word, $\gamma \lambda \omega \sigma \sigma o \mu \alpha v i \alpha$, perhaps coined by himself, which had the potential to evoke strong feelings regarding the 'manic' use of language not only in the historical past, by Cynic philosophers in fourth-to-third-century в С Athens, but also in his own cultural and religious context, second-century AD Christianity, which experienced such a phenomenon in the course of the rise and spread of a prophetic movement such as Montanism. 